
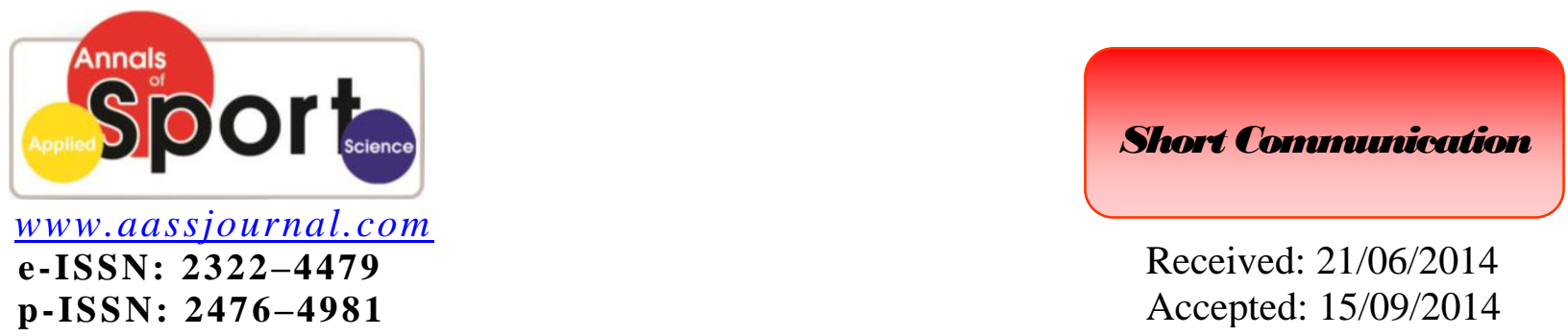

Received: $21 / 06 / 2014$

Accepted: 15/09/2014

\title{
The Effect of 8 Weeks Aerobic Training on the Social Adjustment in Mentally Retarded Children with Hemiplegic Cerebral Palsy
}

\author{
Zahra Pooraghaei Ardakani*, Forough Rahmati
}

- Department of Motor Learning, Faculty of Physical Education and Sport Science, Allameh Tabataba'i University, Tehran, Iran.

\begin{abstract}
One of the most important and basic problems in mentally retarded children which can form the basis of their behavior is impairment in social adjustment and performance. The purpose of the present work was to study the effect of 8 weeks aerobic training on the social adjustment in mentally retarded children with hemiplegic cerebral palsy. The statistical population included all mentally retarded children with hemiplegic cerebral palsy in District 1 of Tehran who were under the coverage of Exceptional Education Organization in 2013-2014 academic year. Among 38 mentally retarded children, 24 (with a mean age of $9 \pm 2$ years) were randomly selected and divided into two groups: experimental and the control groups. To assess the social adjustment, Vineland Adjustment Behavior Scale (VABS) (1984) was used. Quasi-experimental method with pretest and posttest design and a control group was used for this research. The findings showed that 8 weeks aerobic exercises could increase the social adjustment in children with hemiplegic cerebral palsy $(\mathrm{P} \leq 0.001)$. Finally, it can be concluded that aerobic exercises have a positive impact on the social adjustment in children with hemiplegic cerebral palsy by increasing their communication with peers.
\end{abstract}

Key Words: Aerobics, social adjustment, physical activity, mentally retarded children, hemiplegic cerebral palsy.

Corresponding Author:

Zahra Pooraghaei Ardakani

E-mail: zpooraghaei@gmail.com 


\section{INTRODUCTION}

Mental retardation, which may begin at age below 18, is a disorder characterized by intelligence function under normal and impairment in adjusted skills (things that a person is normally expected to do at any age) (1). This impairment causes disorders in a person's ability to function independently, sense of responsibility, and domination over sensory-motor actions, acquisition of necessary skills for academic activities, and running the routine affairs related to life and job (2).

Effect of Aerobic Training on the Social Adjustment of Children with Hemiplegic Cerebral Palsy

Hemiplegia is one of the types of cerebral palsy in which the entire left or right side of the body is completely paralyzed or its motion is limited. This disease is the most prevalent type of paralysis in human and its causes, in most cases, include involvement of the pyramidal and cortical-spinal passages, damage to the motor cortex, and bleeding or blood clot in the brain (3).

Children with cerebral palsy have certain and special conditions. They often have a short attention span, a low self-esteem, faced with difficulties in developing relationships with the outside world, family and peers, and are easily frustrated (4). In general, behavioral problems of mentally retarded children can be divided into two categories: external behavior and internal behavior. Children who are extrovert usually show aggressive behaviors and, in contrast, introvert ones are usually loner and secluded (5). Research studies have shown that children with cerebral palsy mostly show internal behaviors, making them to be faced with stressful events and successive failures (6). Weaknesses in social development can be mentioned as the cause of behavioral problems of mentally retarded children, especially those who suffer from physical disabilities.

In fact, a child's social skills and social interactions with the surrounding environment are the basis of his/her social behaviors (7).
Social adjustment makes children to grow socially and as well would be the reason for their next successes and adjustment. In fact, socialization is a behavior which allows children to understand and predict the behavior of others, control their own behaviors, and adjust their interaction with others (8). Children acquire a more reliable self-perception, more effective inhibition of excitements, social skills and moral principles in pre-school period, while these characteristics are very immature in mentally retarded children (9). In fact, mentally retarded children are highly self-centered and hardly influenced by others, which lead to lack of accountability and progress in their social skills and also incidence of inappropriate behaviors because of lack of understanding of others and the environment (10).

Nowadays, sport has a great role in the treatment of many diseases and physical disabilities. In fact, sport is not only one of the major non-medication treatments but is also known as a complementary and alternative medicine (11). Sports activities increase the spirit of cooperation and competition in children. Children can learn social rules when performing motor activities and exercises, and also improve the necessary creativities and physical capabilities for life. Aerobics is one of the group rhythmic sports that children are very interested in, which creates a lot of happiness and joy; it is inexpensive and safe, and it can be easily done at home without the need of special tools (12). These exercises include 32-beat chain motions composed of 4beat or 8-beat motions. As aerobics is done collectively and because of its close relationship with the social adjustment issue, it can be effective in improving this important factor (13). Also, studies have shown that physical activities with music such as aerobics have a great and positive impact on various social and mental aspects of mentally retarded children, including psychological and social development and memory (14). In fact, 
aerobics stimulates motor development and growth in children and, because it is accompanied by music which encourages children to be active and not give up, it increases the spirit of cooperation and competition in them (11). Participation in physical activities, especially team sports plays a fundamental role in strengthening the five senses, controlling the organs, and coordination in disabled children. Through relationships with the teammates, children can show their emotions to them, express their fears and doubts, experience to love others, learn to respect the rights of others and observe the rules, and can actually achieve social adjustment (15).

Social adjustment refers to a set of learned and acceptable behaviors which enables a person to develop effective relationships with others and refrain from social irrational reactions (16). In this regard, mentally retarded children with hemiplegic cerebral palsy have so many difficulties.

Rhythmic activities, by repeating the sequence of time, increase the behavioral changes, facilitate the acquisition of motor experiences, and provide a broader range of adjusted responses. Additionally, supports are provided for the new adjusted behaviors until they are fully evolved and available to a person (17). It should be mentioned that most studies on mentally retarded children with cerebral palsy have focused on their academic and motor performance and their psychological components and adjustive behaviors have been less taken into account. Hence, the present study, aiming to enhance one of the most important aspects of social development, seeks an answer to the question: can aerobic exercises improve the social adjustment of mentally retarded children with cerebral palsy or not.

\section{MATERIALS AND METHODS}

This study was a quasi-experimental survey with pretest and posttest design and a control group.
Participants. This study was a quasiexperimental survey with pretest and posttest design and a control group. Statistical population included all mentally retarded children with hemiplegic cerebral palsy in District 1 of Tehran and who were under the coverage of Special Education Organization in 2013-2014 academic year. These children were mostly congenitally paralyzed in the arm and hand of one side of the body. Among 38 mentally retarded children, 24 (10 boys and 14 girls) (with a mean age of $9 \pm 2$ years) were randomly selected. After equalization based on clinical observations of instructors on interpersonal and intrapersonal social relationships of children and IQ test scores, they were divided into two groups of experimental and the control. It should be noted that the motor ability of children was taken into account in selecting them for the study and those with mild motor disability who could walk without using auxiliary tools were included in the sampling. In addition, the written agreement of the parents for participation of their children in this study was collected.

Tools. To gather information on children's social adjustment, the instructors and parents of children were asked to answer the Vineland Adjustment Behavior Scale (VABS). This questionnaire was developed in 1984 and is a revised version of Vineland Social Development which was firstly published in 1935. This scale measures the social competence of healthy and disabled children from birth to the age of 19 (18). The class edition consists of 24 items that was completed by the teacher. The interview edition was completed by the parents and it has two forms: survey form consisting of 297 items and the comprehensive form with 577 items. In the present study, the survey form was used. In both editions, the items were scored from 0 to 2; 0 (never does activity), 1 (sometimes does activity) and 2 (usually or habitually does activity). This scale evaluates behavior in four areas: communication, daily life skills, socialization and motor skills, and maladaptive 
behavior. This scale has been standardized in Iran on 2900 children for class edition and 3000 children for interview edition. This scale has a high reliability; 62 to $78 \%$ among the raters, 81 to $86 \%$ for test-retest, and 83 to $90 \%$ for internal consistency. Also, its validity has been reported to be moderate to high (19).

Study Design. The present study was a quasi-experimental survey in which the social adjustment questionnaire was answered by instructors and parents under the supervision of the author. This questionnaire consists of two parts: general part including demographic information of individuals (age, gender, etc.) and specialized part dealing with questions related to Vineland Adjustment Behavior Scale. Then, aerobic exercises, which were designed after consultation with 3 experienced instructors of this sport, were performed. These exercises were done for 8 weeks with three 40-min sessions per week. Each session included 10 min warm-up, 20 min main aerobic exercises and $10 \mathrm{~min}$ relaxation and cooling. It should be noted that motion chains included four very simple movements with two replicates, so that the subjects could easily imitate the author. The music was also designed with a slow rhythm and a low beat per minute (BPM). During this period, the subjects in the control group did not participate in any regular and organized sport activity.

Statistical Analysis. After collecting the required data from $\mathrm{VABS}$, descriptive statistics including frequency of distribution, measures of central tendency and dispersion were used. Also, inferential statistics including Kolmogorov-Smirnov test (to determine the normal distribution of data), Levin test (to determine the homogeneity of variances) and analysis of variance with repeated measures, at a significance level of $\mathrm{p} \leq 0.05$ were used. All statistical analyses were done in SPSS 20 software.

\section{RESULTS}

The level of Social Adjustment, without observance of sphericity assumptions (Mauchly's W=0.327; p=0.001) and using Greenhouse-Geisser adjustment, the effects of time over, group, and interaction effect of time over and group $[(\mathrm{F}=6067.426),(\mathrm{F}=19.75)$, and $(\mathrm{F}=7044.485)$, respectively] was significant $[(\mathrm{p}=0.001), \quad(\mathrm{p}=0.001), \quad$ and $\quad(\mathrm{p}=0.001)$, respectively]. The effects of time over and interaction effect of time over and group was both linear $(\mathrm{p}=0.001)$ and quadratic $(\mathrm{p}=0.001)$ significance type (graph 1).

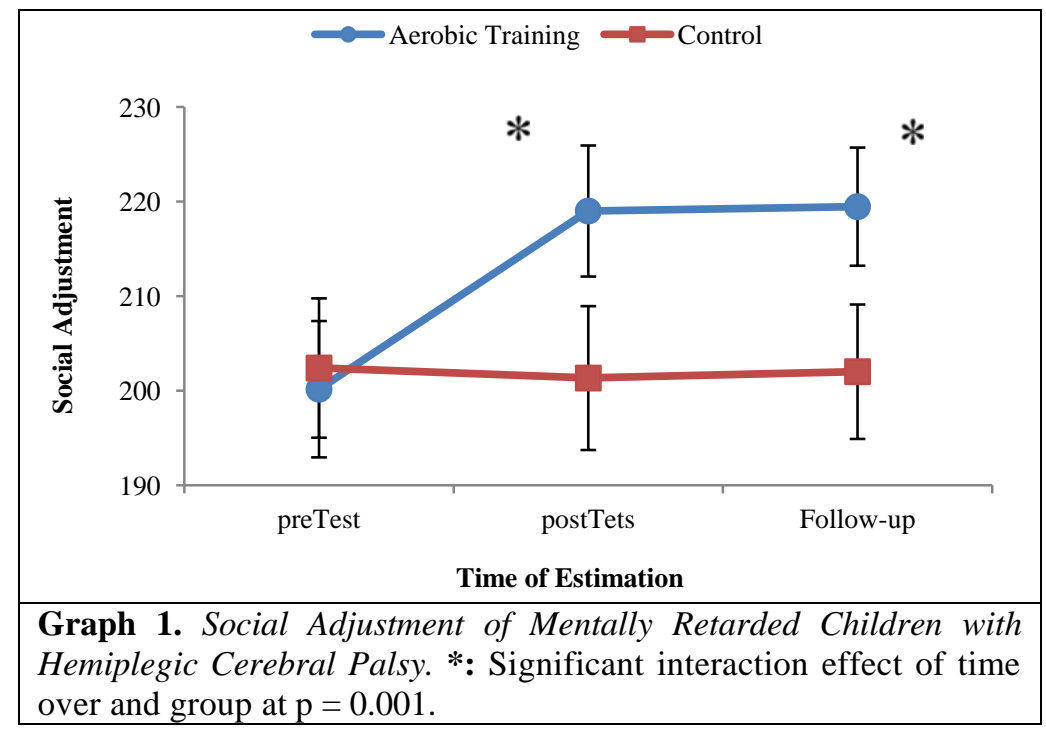

Pooraghaei, Z. Ardakani., Rahmati, F. (2015). Ann Appl Sport Sci, 3(3): 09-16. 


\section{DISCUSSION AND CONCLUSION}

The aim of the present paper was to study the effect of aerobic exercises on the social adjustment of mentally retarded children with cerebral palsy. The findings revealed that variations in the experimental group after aerobic exercises are significant and rhythmic aerobic exercises have been effective positively in the social adjustment of mentally retarded children with cerebral palsy. The results is in consistent with the findings of Lindsay (2012), Aisen (2011), Orlin (2010), Slaman (2010), Palisano (2009) and Clarke (2008) $(9,20-24)$.

The probable reason for the promotion of the social adjustment level of the subjects is the increased interpersonal communications through participation in exercise and learning the social skills. Also, in terms of the role of sport and physical activities in promoting the social components and skills in children with special requirements, a general attitude towards the recognition of the interaction between body and mind can be dealt with, which indicates that the level of emotional, cognitive and physical disorders originate from the intervention of some levels of body movement (25). Motion is the first way through which a child interacts with the environment, in other words, motor skills are a direct response to sensory input from the environment (24). Physical activities, especially rhythmic ones facilitate children's meaningful discovery of self and the world around them and they try to create a coherent body image and expand the motor treasury for developing the appropriate adjusted skills (2). Children with cerebral palsy can benefit from the rhythmic physical activities as a method of movement therapy at multiple levels. The tactile and movement stimulation resulting from such activities makes a stronger body image and integration of sensory perception of other peripheral components (26). Together with being enjoyable and getting the whole body involved, motor activities help children maintain their focus and attention and control the behaviours caused by the immediate stimulants. This creative method focuses on the uniqueness of each child as a value more rather than their talents in the movement therapy process, and helps children repair their concept of self which has been damaged by the repeated failures and, in fact, create the ability to repair damaged social adjustment in children, so that they can develop appropriate social relationships with their peers (27).

Actually, sport activities with music are the prescribed and organized application of music under the supervision of trained personnel in order to improve the maladaptive conditions and help the mentally retarded individuals to achieve the therapeutic goals (28). In explaining the effect of rhythmic movements on children's psychological factors, worldwide studies have shown that early stimulation is very important for the brain development. An environment teemed with proper stimulations can strengthen the neural connections in the brain of children. As a result, the brain would be adjusted and flexible from the early stages of growth and the problems caused by inappropriate growth can be somewhat improved. When there is a disorder in the normal development of a child, neural connections are not formed properly and the child will not have the ability to receive and understand the environmental 
stimulations (29). In fact, several evidences suggest that children's mental growth and learning are affected by their experiences and even pre-birth experiences can be effective in future learning. The most obvious role of physical activity with music in children is to expand their experiences (9).

The results of the present study indicating the effectiveness of rhythmic exercises on the social adjustment of mentally retarded children with cerebral palsy.

\section{APPLICABLE REMARKS}

- It is recommended that sport exercise, especially rhythmic ones should be offered to all students with special needs, so that they can improve their social and adjusted behaviours.

- Providing the opportunities and experiences that increase social interaction makes children to learn social skills and strategies, and apply them in all environments and real-life situations.

\section{REFFRENCES}

1. De Groot S, Janssen TW, Evers M, Van der Luijt P, Nienhuys KN, Dallmeijer AJ. Feasibility and reliability of measuring strength, sprint power, and aerobic capacity in athletes and non-athletes with cerebral palsy. Developmental Medicine \& Child Neurology. 2012;54(7):647-53.

2. Whittingham K, Fahey M, Rawicki B, Boyd R. The relationship between motor abilities and early social development in a preschool cohort of children with cerebral palsy. Research in developmental disabilities. 2010;31(6):1346-51.

3. Verschuren O, Ketelaar M, Gorter JW, Helders PJ, Takken T. Relation between physical fitness and gross motor capacity in children and adolescents with cerebral palsy. Developmental medicine \& child neurology. 2009;51(11):866-71.

4. van der Burg JW, Jongerius P, van Limbeek J, van Hulst K, Rotteveel J. Social interaction and self-esteem of children with cerebral palsy after treatment for severe drooling. Eur J Pediatr. 2006;165(1):37-41.

5. Balemans A, Van Wely L, De Heer S, Van den Brink J, De Koning JJ, Becher JG, et al. Maximal aerobic and anaerobic exercise responses in children with cerebral palsy. Medicine and science in sports and exercise. 2013;45(3):561-8.

6. Colver AF, Dickinson HO, Parkinson K, Arnaud C, Beckung E, Fauconnier J, et al. Access of children with cerebral palsy to the physical, social and attitudinal environment they need: a cross-sectional European study. Disability \& Rehabilitation. 2011;33(1):28-35.

7. Butler JM, Scianni A, Ada L. Effect of cardiorespiratory training on aerobic fitness and carryover to activity in children with cerebral palsy: a systematic review. International Journal of Rehabilitation Research. 2010;33(2):97-103.

8. Voorman JM, Dallmeijer AJ, Van Eck M, Schuengel C, Becher JG. Social functioning and communication in children with cerebral palsy: association with disease characteristics and personal and environmental factors. Developmental Medicine \& Child Neurology. 2010;52(5):441-7.

9. Lindsay S, McPherson AC. Experiences of social exclusion and bullying at school among children and youth with cerebral palsy. Disability and Rehabilitation. 2012;34(2):101-9.

10. Fowler EG, Knutson LM, DeMuth SK, Siebert KL, Simms VD, Sugi MH, et al. Pediatric endurance and limb strengthening (PEDALS) for children with cerebral palsy using stationary cycling: a randomized controlled trial. Physical therapy. 2010;90(3):367-81.

11. Ghanbari B, Saadat M. The Effectd of Yoga Rhythmic Movements on the Social Interactions of Children with Mental Deficiency. Foundations of Education. 2010;11(1):171-88 [Article in Farsi].

12. Mogharnasi M, Koushan M, Golestaneh F, Seyedahmadi M, Keavanlou F. The Effect of Aerobic Training on the Mental Health of Addict Women. 2. 2011;18(2):91-7 [Article in Farsi].

13. Hadavandkhani F, Mirzamani SM. Effect of musical Activities on short-term memory of mentally-retarded students. Research on Exceptional Children. 2008;8(3):307-16 [Article in Farsi].

14. Clanchy KM, Tweedy SM, Boyd R. Measurement of habitual physical activity performance in adolescents with cerebral palsy: a systematic review. Developmental Medicine \& Child Neurology. 2011;53(6):499-505.

Pooraghaei, Z. Ardakani., Rahmati, F. (2015). Ann Appl Sport Sci, 3(3): 09-16. 
15. Aliakbari Dehkordi M, Dadkhah A, Mehrdadfar F, Mohtashami T, Kordestani D. The Effectiveness of Dohsahou Psycho-Rehabilitation on Social Interaction in Children with Cerebral Palsy. Iranian Journal of Exceptional Children. 2011;11(2):245-54 [Article in Farsi].

16. Ragonesi CB, Chen X, Agrawal S, Galloway JC. Power mobility and socialization in preschool: a case study of a child with cerebral palsy. Pediatric Physical Therapy. 2010;22(3):322-9.

17. Jenaabadi H. Efficacy of Social Skills Training on Behaviour Disorders Among Fifth Grade Exceptional Students In Kosar Elementary School of Zahedan In Academic Year 88-89. Quarterly Psychology of Exceptional Individuals. 2011;1(2):73-83 [Article in Farsi].

18. Clemm H, Røksund O, Thorsen E, Eide GE, Markestad T, Halvorsen T. Aerobic capacity and exercise performance in young people born extremely preterm. Pediatrics. 2012;129(1):e97-e105.

19. Beh Pajooh A, Soleymani M, Afrooz GA, GholamAli M, Lavasani. A Study on the Impact of Social Skill Training on Social Adjustment and Academic Performance in Slow Learners. Journal of Educational Innovations. 2010;9(33):163-86 [Article in Farsi].

20. Aisen ML, Kerkovich D, Mast J, Mulroy S, Wren TAL, Kay RM, et al. Cerebral palsy: clinical care and neurological rehabilitation. The Lancet Neurology. 2011;10(9):844-52.

21. Clarke M, Wilkinson R. Interaction between children with cerebral palsy and their peers 2: Understanding initiated VOCA-mediated turns. Augmentative and Alternative Communication. 2008;24(1):3-15.

22. Orlin MN, Palisano RJ, Chiarello LA, KANG LJ, Polansky M, Almasri N, et al. Participation in home, extracurricular, and community activities among children and young people with cerebral palsy. Developmental Medicine \& Child Neurology. 2010;52(2):160-6.

23. Palisano RJ, Kang L-J, Chiarello LA, Orlin M, Oeffinger D, Maggs J. Social and community participation of children and youth with cerebral palsy is associated with age and gross motor function classification. Physical Therapy. 2009;89(12):1304-14.

24. Slaman J, Roebroeck M, van Meeteren J, van der Slot W, Reinders- Messelink H, Lindeman E, et al. Learn 2 Move 16-24: effectiveness of an intervention to stimulate physical activity and improve physical fitness of adolescents and young adults with spastic cerebral palsy; a randomized controlled trial. BMC Pediatr. 2010;10(1):1-8.

25. Dickinson HO, Colver A. Quantifying the physical, social and attitudinal environment of children with cerebral palsy. Disability and Rehabilitation. 2011;33(1):36-50.

26. Kang L-J, Palisano RJ, Orlin MN, Chiarello LA, King GA, Polansky M. Determinants of social participationwith friends and others who are not family members-for youths with cerebral palsy. Physical therapy. 2010;90(12):1743-57.

27. Howcroft J, Klejman S, Fehlings D, Wright V, Zabjek K, Andrysek J, et al. Active video game play in children with cerebral palsy: Potential for physical activity promotion and rehabilitation therapies. Archives of physical medicine and rehabilitation. 2012;93(8):1448-56.

28. Larijani ZS, Razeghi N. Impact of Art Therapy on Social Development in Students with Intellectual Disabilities. Research On Exceptional Children. 2008;8(1):43-52 [Article in Farsi].

29. Verschuren O, Ketelaar M, Keefer D, Wright V, Butler J, Ada L, et al. Identification of a core set of exercise tests for children and adolescents with cerebral palsy: a Delphi survey of researchers and clinicians. Developmental Medicine \& Child Neurology. 2011;53(5):449-56. 
تازههاى علوم كاربردى ورزش

مقاله كوتاه

دوره سوم، شماره سوم

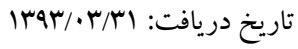

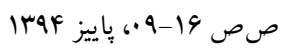

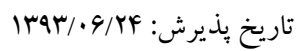

\section{اثر هشت هفته تمرين ايروبيك بر ساز كارى اجتماعى كودكان كم توان ذهنى مبتلا به فلج مغزى همى يلزى}

$$
\text { 'زهرا بور آقايى اردكانى *، 'فروغ رحمتى }
$$

1. استاديار كروه رفتار حركتى، دانشكده تربيت بدنى و علوم ورزشى، دانشكاه علامه طباطبائى، تهران، ايران.

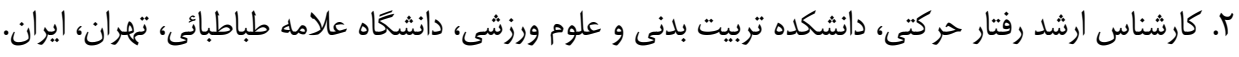

جكيده

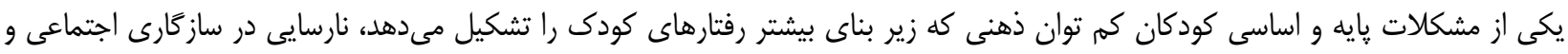

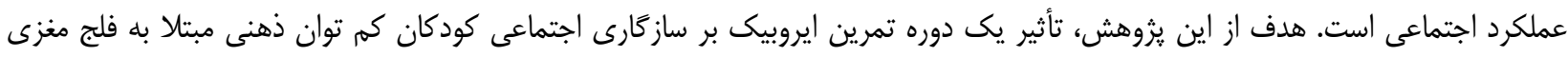

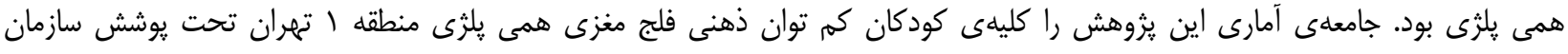

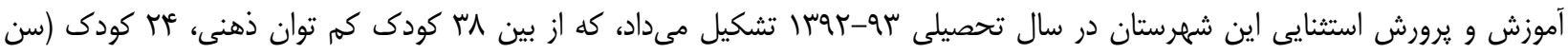

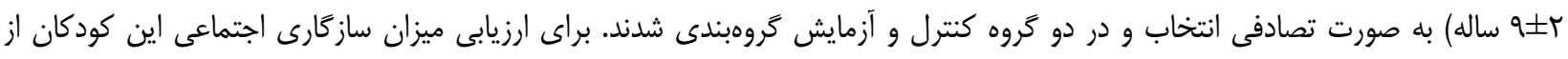

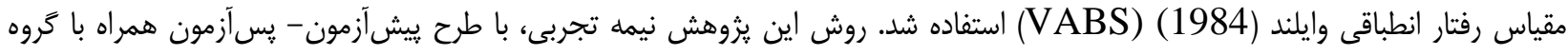

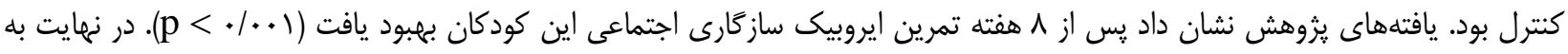

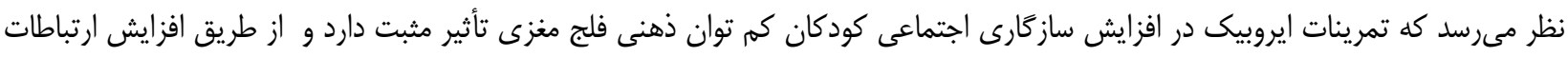

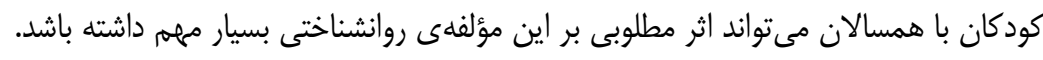

وازَّان كليدى: ايروبيك، سازكارى اجتماعى، فعاليت بدنى، كودكان استنايى، فلج مغزى، همى يلزى.

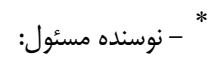

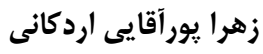

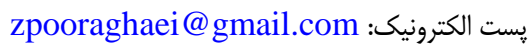

